\title{
Dolomite Deposit
}

Near Marble

\section{Stevens}

County

\section{Washington}

By CHARLES DEISS

\section{A CONTRIBUTION TO ECONOMIC GEOLOGY}

G E O L O I C AL S U R V E Y B U L L E T I N 1027-C

A study of the geologic structure and petrology of a dolomite deposit

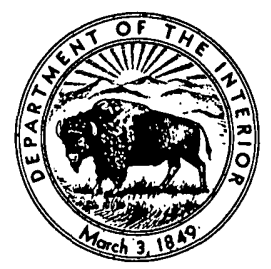


UNITED STATES DEPARTMENT OF THE INTERIOR

Douglas McKay, Secretary

\author{
GEOLOGICAL SURVEY
}

W. E. Wrather, Director

For sale by the Superintendent of Documents, U. S. Government Printing Office Washington 25, D. C. 


\section{CONTENTS}

\begin{tabular}{|c|c|}
\hline \multirow{2}{*}{ Abstract... } & Page \\
\hline & 119 \\
\hline - & 120 \\
\hline cation of deposit & 120 \\
\hline dimentary rocks. & 121 \\
\hline Northport limestone & 122 \\
\hline Glacial drift $\ldots$ & 122 \\
\hline - & 123 \\
\hline neous rocks $\ldots \ldots$ & 125 \\
\hline Lamprophyre dikes....... & 125 \\
\hline Petrography of the dike rocks. & 126 \\
\hline ic significance of the dikes & 128 \\
\hline eologic structure............ & 128 \\
\hline Fal & 129 \\
\hline . & 129 \\
\hline in the quarry face & 130 \\
\hline 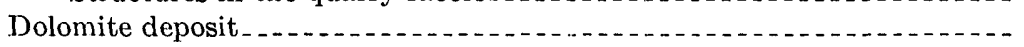 & 130 \\
\hline the dolomite... & 130 \\
\hline Ies & 132 \\
\hline 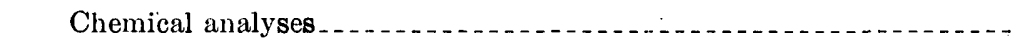 & 132 \\
\hline and position of selected samples....... & 132 \\
\hline r impurities. & 135 \\
\hline e dolomite & 138 \\
\hline lining conditions and methods & 139 \\
\hline Quarry operations & 140 \\
\hline Crushing and screening & 140 \\
\hline duction . . & 140 \\
\hline lected bibliography . . . . . . . & 141 \\
\hline
\end{tabular}

\section{ILLUSTRATIONS}

PuATe 14. Geologic map of dolomite deposits near Marble, Stevens County, Wash.......... In pocket

15. Structure sections of dolomite deposits near Marble..... In pocket

FIGURE 28. Index map showing location of dolomite deposit.... 121

29. Southeast side of dolomite deposit................... 124

30. Locations of igneous rock specimens and analyzed dolomite

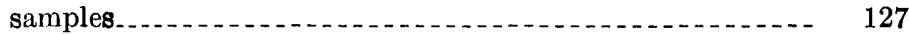

31. Central part of quarry face

32. Continuous white quartz vein on intersecting joints....... 136

33. Irregularly intersecting vuggy quartz veins in dark-gray dolomite.

36. I arge vin of white quartz

36. Large vein of white quartz

37. Buff-colored quartz surrounding leached fragments of dolomite breccia. 


\section{TABLES}

TABLE 1. Chemical analyses of dolomite samples 1-35

2. Chemical analyses of dolomite samples $36-43$ 


\title{
A CONTRIBUTION TO ECONOMIC GEOLOGY
}

\section{DOLOMITE DEPOSIT NEAR MARBLE, STEVENS COUNTY WASHINGTON}

\author{
By Charles Deiss
}

\section{ABSTRACT}

The dolomite deposit 2 miles east of Marble in the northern part of Stevens County, Wash., was studied in detail during short periods in 1942, 1943, and 1944 by geologists of the U. S. Geological Survey. The deposit constitutes an isolated hill that trends northeast, is partly covered by glacial drift, and is surrounded by glacial lake sands, silts, and gravels. The dolomite is part of the Northport limestone, which is tentatively assigned to the Cambrian and is overlain by the Mission argillite of Weaver (1920), the youngest formation in the Stevens series of Weaver (1920).

The deposit is on the southeast limb of the Northport anticlinorium. The rock is strongly jointed and is broken by at least six dip-slip(?) normal faults that are found in two sets. The older set strikes N. $55^{\circ}-60^{\circ} \mathrm{E}$. and dips $66^{\circ}-78^{\circ} \mathrm{NW}$.; the younger set strikes $\mathrm{N} .10^{\circ}-23^{\circ} \mathrm{E}$. and dips $72^{\circ}-80^{\circ} \mathrm{W}$., offsetting the older set. At least 9 lamprophyre dikes, whose outcrops range from 4 to 25 feet in width and from 20 to 180 feet in length, have intruded along faults or along joints parallel to faults. Contact minerals or other impurities are not associated with the dikes.

The dolomite is commonly light gray, but at a few places it is banded dark gray. The dolomite is finely crystalline, thick bedded, and massive; and certain areas within it contain quartz in the form of veins, nodules, vuggy masses, and breccia cement. The silica probably was deposited by hydrothermal solutions and, in some places, is sufficiently abundant to prevent commercial exploitation of the dolomite. The dolomite is a bedded sedimentary deposit and dolomitization probably occurred at, or shortly following, the time of deposition. This is indicated by the lack of characteristics typical of hydrothermal replacement deposits.

The deposit is readily accessible for open-pit mining. Analyses of the ore shipped and the amount of quartz observable in the outcrops suggest that the impurities in the deposit average more than $2 \frac{1}{2}$ percent.

From the time the quarry was opened, in April 1943, till November 1943 an average of about 19,500 tons of ore per month was shipped to Spokane, Wash. In mid-November 1943 production was cut to less than half of the previous tonnage. Mining activity ceased by January 1,1945 . 


\section{INTRODUCTION}

The dolomite deposit near Marble was studied in order to make an accurate geologic and topographic map showing the distribution of the dolomite and of other rocks and impurities in the deposit. The dolomite was studied also to determine the geologic structures that might affect exploitation of the deposit. As dolomite is a relatively new ore of magnesium, knowledge gained from this intensive geologic study may prove useful in establishing criteria for evaluating unworked deposits.

The first geologic field work near Marble was done in 1942 by J. M. Hill and B. N. Webber, of the Electro Metallurgical Co. The U. S. Geological Survey, as a part of its search in the West for dolomite that might be used as a source of magnesium, began fieldwork near Marble on September 17, 1942, when a stratigraphic section (p. 134) was measured and 35 rock samples (p. 134) were collected. Between October 4 and November 22, 1943, the area was mapped on a scale of 1:2,400. The deposit was revisited briefly by the writer in September 1944.

G. E. Ericksen assisted the writer throughout the fieldwork and aided in the preparation of the maps and structure sections. F. W. Sandoz, quarry superintendent, Spokane Portland Cement Co., furnished a private map of the property and information concerning mining, milling, and production. E. H. Mangan, general superintendent (1942-44), Spokane Works, Electro Metallurgical Co., granted permission to study the deposit. The late E. S. Leaver of the U. S. Bureau of Mines, Reno, Nev., supervised the chemical analysis of samples 1 to 35. Harold E. Culver, supervisor, Washington Division of Geology, visited the deposit while the fieldwork was in progress and made helpful suggestions concerning glacial deposits in the region.

\section{LOCATION OF DEPOSIT}

The dolomite deposit is on the southeast side of the Columbia River and is 2 miles N. $80^{\circ} \mathrm{E}$. of Marble, a station on the Great Northern Railroad (fig. 28). The nearest town is Northport, Wash. A railroad spur, formerly owned by the Defense Plant Corp., extends from the screening plant at the deposit (pl. 14) to the Great Northern track south of Marble.

The dolomite forms an isolated hill which trends N. 55 $\mathrm{E}$. The hill is 3,560 feet long, is 1,340 feet wide at the widest part, was sculptured by glacial ice, and is partly covered by till and stratified drift. The highest point of the hill (altitude 2,077 feet) is 285 feet above the flat to the south and 335 feet above the flat to the north (pl. 14). Most of the deposit is in the NE $1 / 4$ sec. 27, T. 39 N., R. 39 E., Willamette 


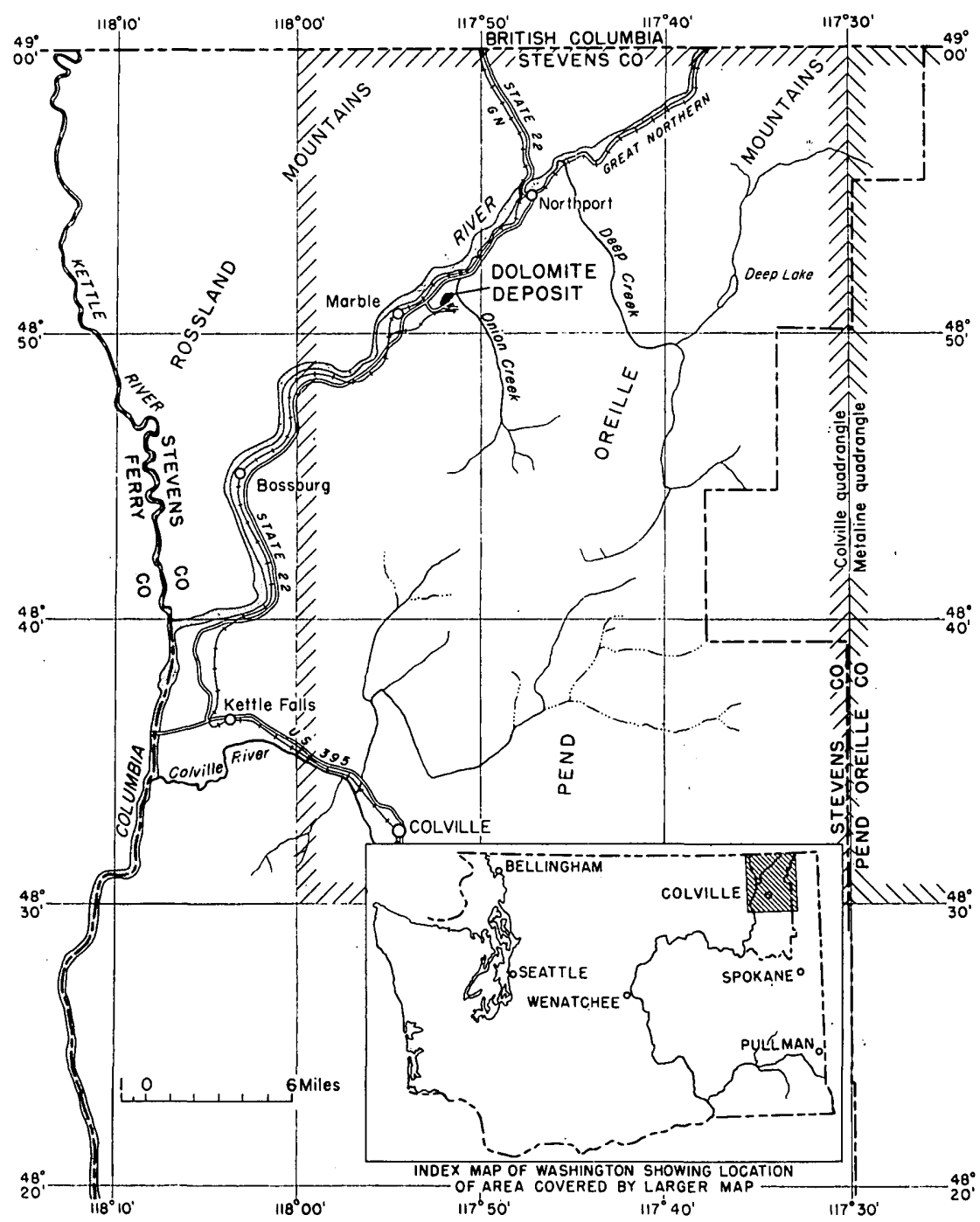

Figure 28.-Index map showing location of dolomite deposit.

meridian, in the northern part of Stevens County, 10 miles south of the Canadian boundary and about 35 miles west of the Idaho boundary.

\section{SEDIMENTARY ROCKS}

Dolomite is the only sedimentary rock exposed in the map area except Pleistocene glacial deposits. The dolomite is within the belt of metamorphosed limestone and argillite, 6 to 8 miles wide, that extends from Northport 16 miles southwestward to Bossburg, Wash. Weaver (1920, p. 75-77) tentatively assigned the dolomite to the Northport limestone and named the argillite Mission argillite (p. 72$75)$. In his summary of the formations Weaver gave 3,000 and 12,000 
feet, respectively, for the thicknesses of the Northport limestone and Mission argillite. He placed the formations in the upper part of his Stevens series (Weaver, 1920, pl. 1) and assigned them doubtfully to the Carboniferous. In his discussion of the lithology of the Northport, Weaver wrote: "The Northport limestone is in reality interbedded with the Mission argillite but as a stratigraphic unit it is so distinct that it has been mapped as a separate formation." As Weaver's Mission argillite does not crop out in or near the dolomite deposit, it will not be discussed in this report.

\section{NORTHPORT LIMESTONE}

According to Weaver, the Northport limestone crops out along the valley of the Columbia River in a belt $21 / 2$ miles wide that extends from the mouth of Kettle River northeastward nearly to the Canadian boundary. The dolomite deposit is within this belt and is part of the Northport limestone. Weaver $(1920$, p. 76$)$ described the formation as follows:

Prevailingly, it is a massive fine-grained white limestone which in places is dolomitic. South of Northport, on both sides of the Columbia River, the rock forms large areas of the surface geology and is typically massive and possesses a pure white color which sometimes passes to a light gray. It is usually finely crystalline but occasionally becomes rather coarse and shows stratification planes:

Much of the formation is metamorphosed limestone, but it probably contains more dolomite than is implied by Weaver's description.

The dolomite deposit is in the lower, thicker unit (main mass) of the Northport limestone shown on Weaver's $(1920$, pl. 1, sec. $A-B$ ) structure section. Until detailed stratigraphic work is done on the upper three formations of Weaver's Sterens series, the name Northport limestone should be restricted to this lower unit. The name is used in the restricted sense in this report. Weaver's map and structure section indicate that the Northport limestone underlies (rather than is interbedded with) his Mission argillite and may be the same as the Clugston limestone of Weaver (1920) which crops out 7 miles southeast of the Marble dolomite deposit.

Weaver (1920, p. 50 and pl. 1) doubtfully assigned the upper formations of the Stevens series to the late Paleozoic, possibly of Carboniferous age. Fossils are unknown from these formations; but because the Northport limestone is similar lithologically to part of the Metaline limestone (Park and Cannon, 1943, p. 17-19), and because the Metaline has yielded Middle Cambrian fossils, the restricted Northport limestone tentatively is assigned to the Middle Cambrian(?).

\section{GLACIAL DRIFT}

The northern part of Stevens County was covered by the Columbia River valley lobe of the Cordilleran ice sheet during the Pleistocene. 
The evidence for and the effects of glaciation in the valley of the Columbia River near the dolomite deposit have been competently discussed by Flint (1936, p. 1869-71, 1874-75). Erratics, patches of till, stratified drift, glacial striae on the bedrock, and ice-cut cliffs show conclusively that the dolomite deposit and the surrounding region were covered by glacial ice.

Glacial drift covers more than a fourth of the dolomite ridge and constitutes most, if not all, of the overburden on the deposit. In mining, the drift is removed by pushing most of it aside with bulldozers and by putting the remainder through the screening plant with the dolomite-the till is discarded as part of the fines. About 200 feet north of the present quarry (fig. 31) the drift is much thicker and more widespread than at the quarry site.

The shape and probably the size of the dolomite outcrop are the results of scour by ice (pl. 15) and of deposition of sands, silts, and gravels by glacial melt waters as the ice stagnated. In general, the till occurs on the dolomite hill, and the stratified deposits form the surrounding flat. The glacial drift is distributed irregularly over the hill, and much of it is confined to a wide irregular band that extends across the summit of the hill from the northeast side to the southwest edge (pl. 14). 'The till in this band conceals most of the faults mapped and may conceal extensions of the dikes. In addition to the main bands of drift, many isolated patches, 5 to 300 feet in length, are irregularly distributed over the hill.

In most of the smaller isolated patches the till is probably less than 10 feet thick, but in the larger areas it is as much as 25 feet thick and may be 50 feet thick. The till consists principally of soil particles mixed with some boulder clay and silt; and it contains many rounded and subangular boulders of quartzite, argillite, gneiss, and granite. Stratified silt and sand are mixed in some places with the till, and talus merges with and partly covers it in places near the base of the hill.

\section{GLACIAL LAKE DEPOSITS}

The valley flat surrounding the dolomite deposit consists of interstratified sands, silts, and gravels (fig. 29) deposited in ice-dammed lakes that were formed by melt waters of glaciers of Wisconsin age. Sediments thus deposited are present along the sides of most of the main valleys in northeastern Washington and are well developed in the valley of the Columbia River near Marble. Flint (1936, p. 1854) suggested:

Most of these bodies of [stratified] drift accumulated in entrants off the major valleys, when the valleys were filled with ice, and the entrants carried streams and lakes that were held to high local base-levels, and acted as catchment 


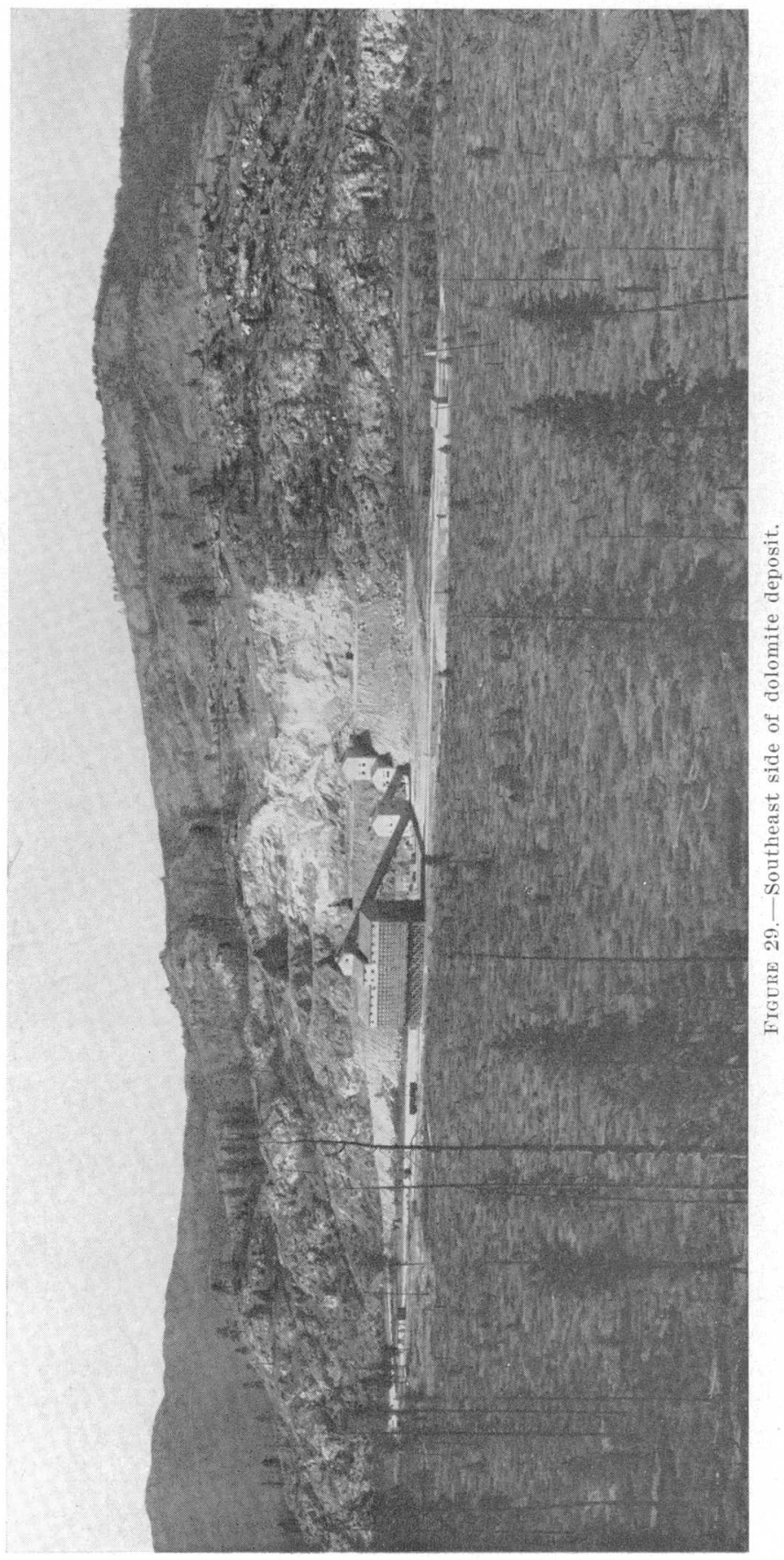


basins for waste contributed chiefly from short tributary streams and from the adjacent slopes.

The unconsolidated sediments that underlie the rolling flat surrounding the dolomite hill may have been desposited in an ice-dammed lake in late Wisconsin time by a stream in the valley of Onion Creek (fig. 28).

In the new railroad cut near the limestone plant, southeast of the dolomite deposit, the following section is exposed:

Sand and silt, slightly weathered in upper part 0.33 to 2.0

Silt and sand, buft-tan, fine-grained

Mud, black, extremely carbonaceous ; some lumps appear to be very dirty lignite

Gravel and sand, interbedded lenses; stratified but generally not well sorted. Some lenses of nearly pure sand 12.0 to 14.0

Total 17.0 to 22.0

The surface of the valley flat surrounding the dolomite hill is gently rolling and has a maximum relief of 82 feet within the area mapped. The flat between the railroad spur and the southeast edge of the hill ranges from 1,790 to 1,800 feet in altitude (pl. 14). Northwest of the hill the altitude ranges from 1,718 to 1,780 feet, the low point being near the north bulge of the hill. Between the isolated dolomite knob (pl. 14) and the southeast corner of the main hill, a block of ice rested while the sediments accumulated around it. The melting of this ice block allowed the sands and silts deposited against and over it to collapse, forming an elongate depression (fossé?) in the valley flat between the end of the railroad and the hill.

Flint (1936, p. 1875) suggested that the stratified deposits along the upper valley of the Columbia River are younger than the Nespelem silt (Pardee, 1918, p. 28), which is a fine-grained facies of the main outwash fill in eastern Washington. In the small area studied by the writer, the lake beds certainly appear to be the youngest Pleistocene deposits, having been laid down during the last melting stage of the youngest Wisconsin glacier. The few isolated mounds of gravel and the erratics on the lake beds near the east end of the hill probably were ice-rafted into the lake or else represent englacial material dropped as the stagnating ice melted.

\section{IGNEOUS ROCKS}

\section{LAMPROPHYRE DIKES}

The Loon Lake granite (Weaver, 1920, pl. 1), exposed 2 miles east of the dolomite deposit, does not intrude the dolomite nor does it seem to have any bearing on the origin or composition of the deposit. Lamprophyre dikes are the only igneous rocks in the deposit. 
The dolomite is intruded by at least nine dikes of medium-grained trachytic lamprophyre, which are irregularly distributed throughout the dolomite hill but are more numerous along its northwest side (pl. 1). Most of the dikes probably intruded along the younger faults or along joint planes parallel to them, and all except two strike between $\mathrm{N} .12^{\circ}$ and $30^{\circ} \mathrm{E}$. and dip between $72^{\circ}$ and $80^{\circ} \mathrm{NW}$. Of the two aberrant dikes, one strikes N. $25^{\circ} \mathrm{W}$., and the other, which intruded along the eastern fault of the older set (pl. 15, sec. $C-C^{\prime}$ ), strikes N. $55^{\circ} \mathrm{E}$.

Outcrops of the dikes range from 4 to 25 feet in width and from 20 to 180 feet in length, and the largest are near the northeast end of the dolomite hill. Several of the dikes are irregularly ovoid in shape and are more like plugs than dikes. All except one are partly covered with till or talus. The most striking characteristics of the dikes are their apparent uniformity of mineral composition and grain size, their orientation parallel to the faults, and the presence in them of xenoliths. Neither contact alteration of the dolomite nor chilled zones in the dikes are apparent. Webber has written about contact relations in a private report: "The lamprophyre dikes have had no appreciable effect on the mass of dolomite. Contact action is confined to a thin, less than $1 \mathrm{inch}$, plate of epidote developed on the walls of the dikes."

The two dikes at the northwest and west ends of the dolomite hill contain xenoliths of quartzite and gneiss. The inclusions are angular and rounded pebbles of quartzite, $i 3 / 4$ to $61 / 2$ inches long and $1 / 4$ to 3 inches wide. One angular fragment of gneiss, 2 inches long and $21 / 2$ inches wide, was seen in the dike at the west end of the hill (fig. 30, sample 11). The contacts between the xenoliths and the lamprophyre are sharp. Possibly some silica was absorbed by the magma, but the quartzite fragments examined megascopically do not appear to be altered.

The source of the quartzite xenoliths may have been the Colville quartzite, which is reported to underlie the Clugston limestone of Weaver in northeastern Washington (Weaver, 1920, p. 68-71). The nearest outcrop of gneiss is the Orient gneiss of Weaver (1920), possibly pre-Cambrian, along the Kettle River, 14 miles west of the dolomite deposit. The xenoliths afford little evidence of the distance that they were carried by the magmas.

\section{PETROGRAPHY OF THE DIKE ROCKS}

The following discussion of the petrography of the igneous rocks was excerpted from an unpublished report by R. L. Smith, who studied the rock specimens and thin sections in the laboratories of the U.S. Geological Survey. The encircled numerals 1 to 11 on the location 


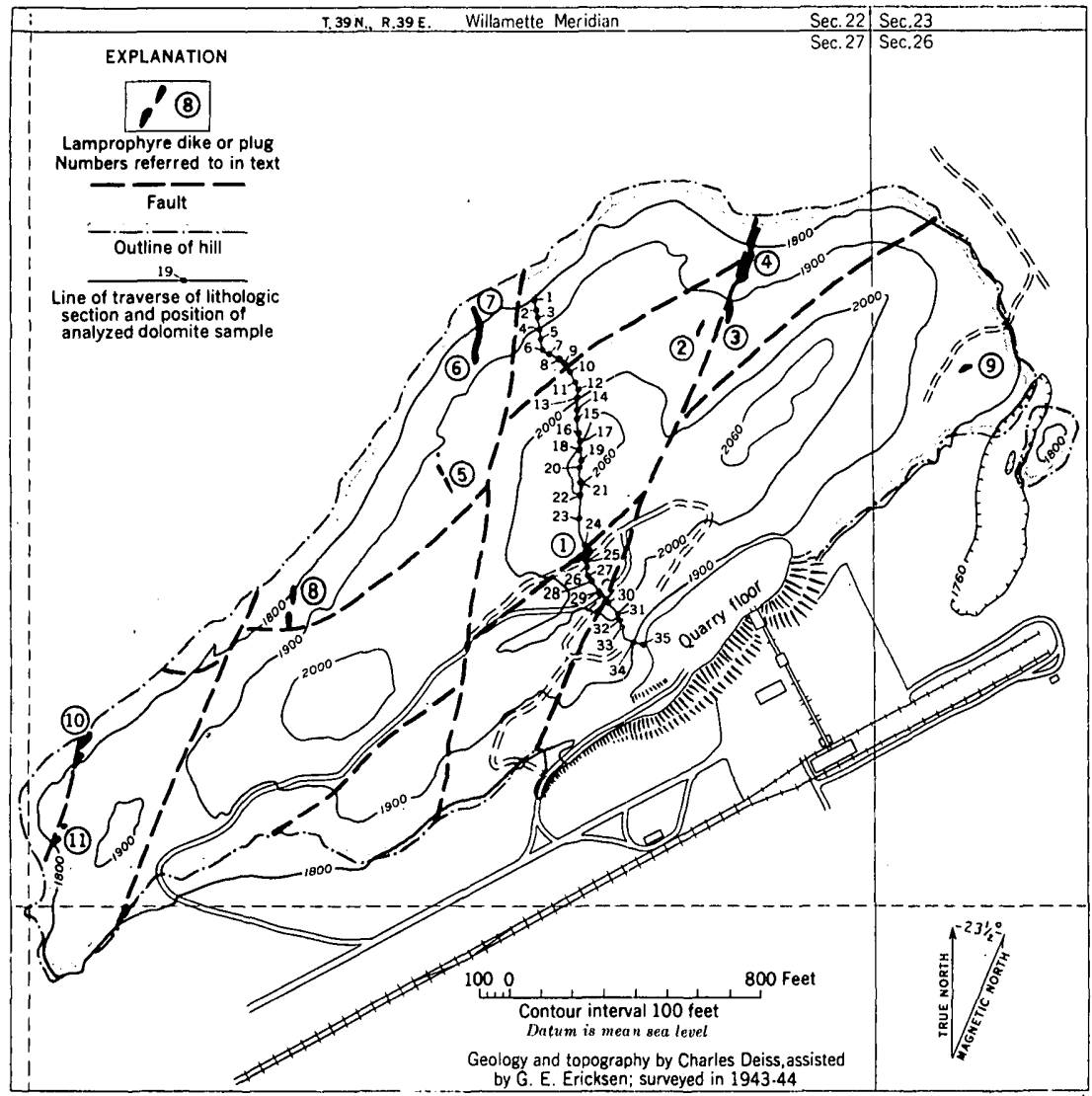

Figure 30.-Locations of igneous rock specimens and analyzed dolomite samples.

map (fig. 30) indicate the dikes from which the respective samples were taken. Smith says:

The eleven igneous rock speciments have been classified as trachytic lamprophyres. They may, however, be segregated into three distinct groups.

A. The first group, which includes nos. 1, 2, 3, and 4 (fig. 30), is characterized by phenocrysts of labradorite and augite, and large phenocrysts of a dark red-brown biotite. The groundmass consists of plagioclase, which is probably sodic-andesine, a large quantity of greenish brown biotite occurring in thin slivers, augite, and a considerable amount of interstitial quartz and orthoclase. Apatite and magnetite are abundant accessory minerals. The nature of the quartz and orthoclase suggests that they crystallized out later than the other minerals.

B. The second group, which includes nos. 5,6 , 7 , and 8 (fig. 30 ), is characterized by its rather uniformly fine-grained texture and by abundant prismatic crystals of hornblende in the groundmass. In addition to hornblende, the groundmass consists of sodic-plagioclase, either oligoclase or sodic-andesine, biotite, augite, a fair amount of interstitial quartz and orthoclase, and accessory apatite and magnetite. A few phenocrysts of biotite and augite are present. 'This group does not contain the combination of two types of biotite present in the first and third groups. 
C. The third group, which includes nos. 10, 11, and probably no. 9 (fig. 30), is characterized by augite and two kinds of biotite, and differs from the first group in that the feldspar is more allzalic, the plagioclase phenocrysts are absent, and more interstitial quartz is present. Nos. 10 and 11 , which are almost identical, are more coarsely crystalline than any of the other rocks. Apatite and magnetite are present as accessories. No. 9 (fig. 30 ) differs from the other two in this group in that it contains no large phenocrysts of biotite, but contains more augite.

Smith states that the rocks in all three groups have to some extent been altered. His report describes also the secondary minerals found in the samples.

\section{ECONOMIC SIGNIFICANCE OF THE DIKES}

The dikes apparently brought in little, if any, of the silica found in the dolomite. Their economic effect would be to increase the cost of selective quarrying and the cost of disposing of dike rock. However, differences in color and texture would make separation from the dolomite easy. None of the dikes is within the block outlined for mining by the Electro Metallurgical Co.

\section{GEOLOGIC STRUCTURE}

The dolomite is part of the southeast limb of a large anticlinorium that extends northeastward along the valley of the Columbia River from Marble to beyond Northport, Wash. Weaver (1920, p. 111) named the fold the Northport anticline and described it as follows:

The Northport limestones and the Mission argillites exposed along the valley of Columbia River form an anticline whose axis trends approximately parallel to the general course of the river. On the northwestern side of the river the dip is prevailingly to the northwest except where there have been local disturbances. On the eastern side of the river the dip is usually to the southeast but in places it is nearly flat. Apparently the fold is a very shallow anticline which has been so deeply eroded that the argillites overlying the Northport limestones have been removed. Faults whose positious have not been determined seem to obscure the general structure. This fold is referred to in this report as the Northport anticline.

Weaver's map (1920, pl. 1) suggests that the anticlinal axis strikes N. $50^{\circ} \mathrm{E}$. The "Northport anticline" probably is an o, en asymmetric anticlinorium, broken by many small strike and oblique normal faults.

The most obvious geologic structures within the dol,mite deposit are joints, which are much more numerous and more easily recognizable than the bedding planes. Slight movement along many of these joints doubtless accomplished much adjustment within the major fold. Local folds were not observed; but two sets of normal faults, on which the displacement probably was not great, cut the dolomite. 


\section{FAULTS}

The dolomite hill is broken by at least six normal dip-slip or obliqueslip faults belonging to two westward-dipping sets (pls. 14, 15). The presence and position of these faults, which are covered most of their length with glacial drift or rock mantle, were deduced from field observations and from a study of aerial photographs of the deposit. As the dolomite in the deposit is nearly homogeneous, the faults will not affect the reserves and probably will not affect quarrying to any marked extent.

The faults in the first or older set trend nearly parallel to the strike of the beds, are subparallel to each other, and are broken by younger faults. Measurements on joint surfaces adjacent to the fault zones suggest that the older faults strike N. $55^{\circ}-60^{\circ} \mathrm{E}$. and dip $66^{\circ}-78^{\circ} \mathrm{NW}$. Because bedding planes are obscured and marker beds are absent in the nearly uniform mass of dolomite, the amount of movement along the faults is unknown (pl. 15), although the throw is apparently 50 to 100 feet on each fault. The block on the northwest side of each fault is downthrown in relation to the block on the east, and each may have been rotated slightly.

The younger oblique dip-slip normal faults (pl. 14) strike N. $10^{\circ}-$ $23^{\circ} \mathrm{E}$. and $\operatorname{dip} 72^{\circ}-80^{\circ} \mathrm{W}$. The older faults are offset 80 to 200 feet; this suggests that the movement on the younger faults may have been greater than movement on the older ones.

Most of the dikes are on, or are subparallel to, the younger faults, indicating that the intrusions occurred after the older faults were formed and at the same time or slightly later than the younger faults. All the faults probably were formed when the compressive stresses that produced the Northport anticlinorium relaxed.

\section{JOINTS}

The dolomite is broken by many joints which may be divided into five sets of high-angle and two sets of low-angle joints. The five high-angle sets (1) strike northeast and dip northwest subparallel to the older set of faults, (2) strike northeast and dip southeast, (3) strike north and dip west, (4) strike northwest and dip southwest, and (5) strike northwest and dip northeast. The two low-angle sets (1) strike northwest and dip northeast, and (2) strike northwest and dip southwest. The high-angle joints range in dip from less than $60^{\circ}$ to more than $80^{\circ}$. Most of the joints are curved and readings taken on different parts of a joint surface may show a variation of $15^{\circ}$ to $25^{\circ}$.

The most prominent joints are subparallel to the older set of faults (pl. 14), strike N. $45^{\circ}-59^{\circ}$ E., and dip $65^{\circ}-74^{\circ} \mathrm{NW}$. Although some of the joints that strike northeast dip southenst, most dip northwest 
and form conspicuous dip-slope cliffs on the northwest side of the hill. The southeastward-dipping joints probably were produced by stresses normal to the fault surfaces and, therefore, may be tension fractures.

The joints parallel to the younger set of faults are less conspicuous than those parallel to the older faults, and they constitute a system composed of three sets. The first set strikes N. $1^{\circ}-5^{\circ}$ E. and dips $62^{\circ}-82^{\circ} \mathrm{W}$.; the second set strikes N. $10^{\circ}-17^{\circ} \mathrm{W}$. and dips $62^{\circ}-80^{\circ}$ SW. ; the third set strikes N. $30^{\circ}-38^{\circ} \mathrm{W}$. and dips $60^{\circ}-84^{\circ} \mathrm{NE}$.

The joints in the dolomite deposit are important because they may have been the paths of ingress for solutions that deposited the silica, and because they greatly facilitate quarrying operations.

\section{STRUCTURES IN THE QUARRY FACE}

The quarry face (fig. 31) exhibits several eastward-dipping, intersecting, curved fault surfaces. The largest one is very curved and exposes a dome-shaped footwall. The fault surface strikes N. $30^{\circ}-50^{\circ}$ E., dips $40^{\circ}-50^{\circ} \mathrm{SE}$., and exhibits large grooves 2 to 4 feet wide that are secondarily grooved. On natural outcrops such striae would be interpreted as glacial in origin, but here they imply that the movement on this fault was horizontal. The surface is also slightly slickensided. Most of the other small faults also are curved (fig. 31), as are many of the joints exposed in the quarry face. A prominent set of joints strikes N. $22^{\circ}$ E. and dips $60^{\circ} \mathrm{NW}$.

The dome-shaped fault may have been formed during the early compressive stage of diastrophism, and the rest of the structures may have developed during a later tensional stage. The intensive jointing and faulting exhibited in the quarry face probably extend throughout most of the hill.

\section{DOLOMITE DEPOSIT}

The dolomite deposit is an isolated hill surrounded by a rolling flat of glacial lake sands, silts, and gravels (fig. 29). The mountain southeast of the flat and the hill to the north are composed of limestone and some dolomitic limestone. The dolomite hill, therefore, appears to be an isolated body within the Northport limestone. The lithologic relations of the dolomite to the limestone cannot be observed because of the surrounding cover. Studies of aerial photographs of the region suggest that the dolomite is slightly offset from, but has the same general strike as, the limestone on the opposite side of valley of the Onion Creek and is in the same part of the formation.

\section{LITHOLOGY OF THE DOLOMITE}

The dolomite is white gray, pale bluish gray, faint buff gray, and dove gray, and large areas are irregularly marked and banded dark 


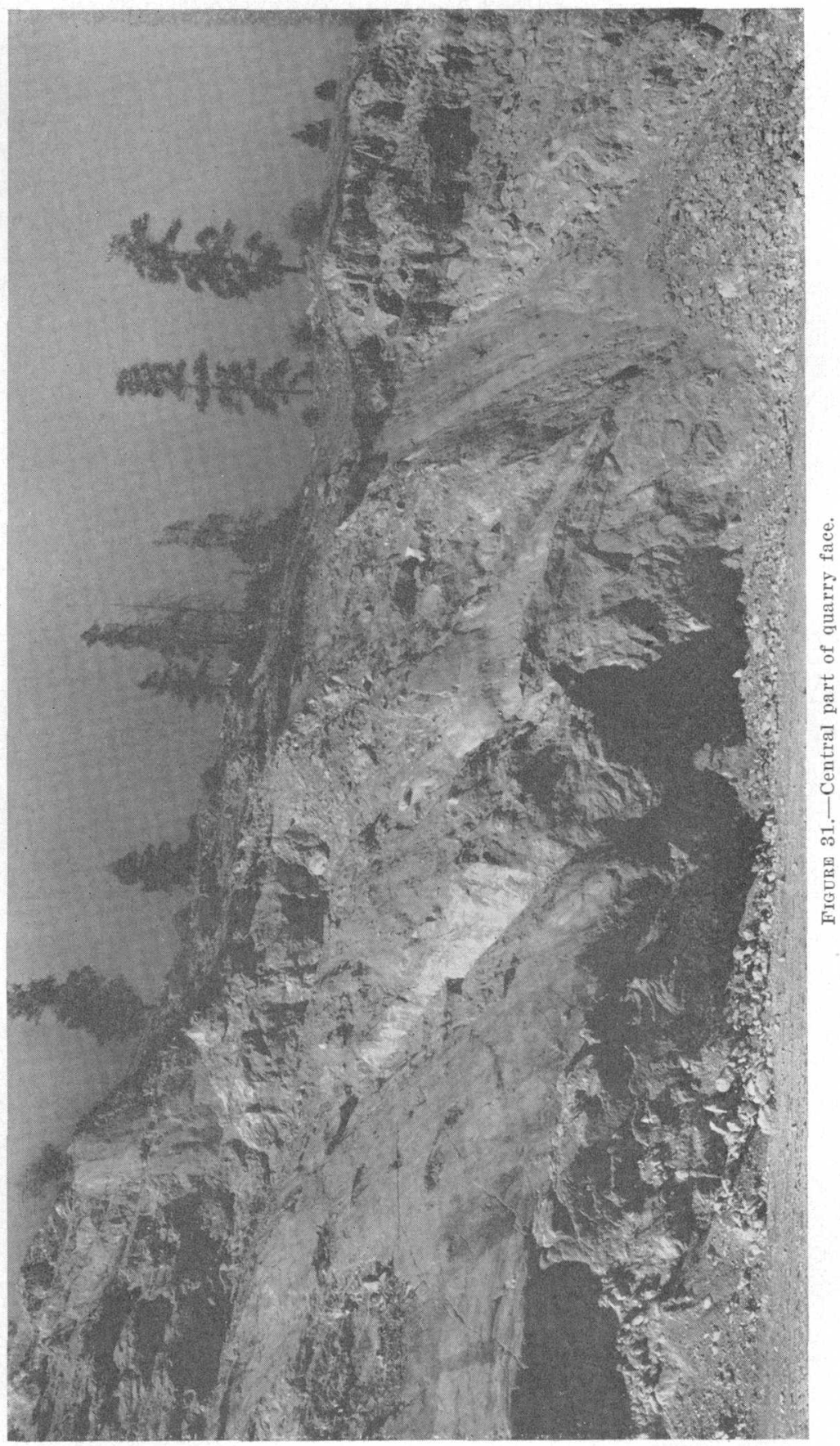


gray. Weathered surfaces are generally lighter in color than freshly fractured surfaces. The dark dolomite ranges from black gray to dull gray and at most places is marked with irregular light-gray spots, stringers, and masses. The small light-gray spots cause a conspicuous mottling, and in places are so numerous and small that they give the rock a coarse salt-and-pepper appearance. Some of the dark bands are parallel to the dolomite beds, but many cut across them irregularly.

The dolomite is dense and hard, and is generally finely crystalline to microcrystalline. Some of the light-gray dolomite is slightly vitreous on fresh fractures. A few of the darker beds are sugary. Some of the white masses in the dark areas are coarse grained, the crystals being as much as three-sixteenths of an inch long. In a few places, usually in association with vuggy quartz veins, the dolomite is stained buff tan (weathered limonite), and a red stain (impure hematite) marks certain breccia zones. Metamorphism has obliterated many of the bedding planes, which probably were obscure and widely spaced originally. Consequently, most of the exposed dolomite appears massive or unbedded. On the northeast end of the ridge the dolomite contains a few thin wavy siliceous bands, parallel to the bedding, which may represent metamorphosed shale partings. If so, they are the only clastic sedimentary rocks observed in the deposit. No beds of limestone and only three veins of coarsely crystalline calcite were Iound.

\section{BRECCIA ZONES}

Short breccia zones, 6 to 36 inches wide, are irregularly distributed in the dolomite. Two kinds of breccia are present. The more abundant type consists of angular fragments of dolomite cemented in a matrix of white or buff quartz (fig. 37). The other type is composed of subangular and a few slightly rounded fragments of light- and dark-gray dolomite cemented in quartz.

\section{CHEMICAL ANALYSES}

The chemical composition of the dolomite is shown in tables 1 and 2. Samples 1 to 35 are of rock taken from different beds in the measured section (p. 134). Their exact location on the deposit is shown on the map (fig. 30). Samples 36 to 39 are of crushed dolomite in grades 1 to 3 and fines; samples 40 and 41 are chip samples taken from the quarry face and along the upper bench of the quarry; samples 42 and 43 are chip samples taken across the strike of the beds in the southern and northern parts of the deposit.

\section{LITHOLOGIC SECTION AND POSITION OF SELECTED SAMIPLES}

The following incomplete section gives details of the lithology of the dolomite and of the stratigraphic position of the analyzed samples 
TAIBL 1.-Chemical analyses (in percent) of dolomite samples 1-35 [A nalyst, E. S. Leaver]

\begin{tabular}{|c|c|c|c|c|c|}
\hline No. & $\begin{array}{c}\text { Ignition } \\
\text { loss }\end{array}$ & $\begin{array}{l}\text { Insolubles } \\
\left(\mathrm{SiO}_{2}\right)\end{array}$ & $\mathrm{R}_{2} \mathrm{O}_{3}$ & $\mathrm{CaO}$ & $\mathrm{MgO}$ \\
\hline 1 & 46.1 & 1.0 & 1.1 & 30.0 & 21.6 \\
\hline 2 & 45.8 & 1.7 & .8 & 29.6 & 21.3 \\
\hline 3 & 46.2 & .6 & .7 & 29.9 & 21.7 \\
\hline 4 & 46. 3 & 1.4 & 1.0 & 30.2 & 21.1 \\
\hline 5 & 46.0 & 2.0 & 1.2 & 29.8 & 20.8 \\
\hline 6 & 47.0 & .7 & .7 & 30.4 & 21.3 \\
\hline 7 & 45.8 & 2. 6 & 1.1 & 29.7 & 21.1 \\
\hline 8 & 46.4 & 1.5 & .5 & 29.9 & 21.4 \\
\hline 9 & 44.5 & 4. 4 & 1.3 & 28.8 & 20.4 \\
\hline 10 & 45.8 & 1.9 & 1.2 & 29.6 & 20.9 \\
\hline 11 & $\dot{4} 6.6$ & .5 & .7 & 30.3 & 20.8 \\
\hline 12 & 46.4 & 1. 3 & .7 & 30.4 & 20.8 \\
\hline 13 & 46.3 & 1.4 & .5 & 30.0 & 21.2 \\
\hline 14 & 46.7 & .6 & .8 & 30. 2 & 21.4 \\
\hline 15 & 45. 7 & 2. 7 & .4 & 29.7 & 21.1 \\
\hline 16 & 47.0 & .5 & 1.0 & 30.3 & 21.5 \\
\hline 17 & 47.1 & .5 & .4 & 30.4 & 21.7 \\
\hline 18 & 46.8 & 1.0 & .4 & 30.1 & 21.6 \\
\hline 19 & 46. 7 & 1.4 & .4 & 30.1 & 21.5 \\
\hline 20 & 46.9 & 6 & .3 & 30.1 & 21.8 \\
\hline 21 & 45.5 & 3.0 & .6 & 29.5 & 21.1 \\
\hline 22 & 44.8 & 4. 5 & .6 & 28.8 & 20.9 \\
\hline 23 & 46.6 & 1.0 & .5 & 30.0 & 21.6 \\
\hline 24 & 46.4 & 1. 7 & .7 & 29.9 & 21.5 \\
\hline 25 & 46.0 & .7 & .4 & 30.0 & 21.6 \\
\hline 26 & 37.0 & 19.6 & .6 & 24.1 & 17.4 \\
\hline 27 & 46. 2 & .6 & .5 & 30.3 & 21.6 \\
\hline 28 & 45.7 & 1.2 & .6 & 29.7 & 21.5 \\
\hline 29 & 45.8 & 2.6 & .6 & 29.6 & 20.9 \\
\hline 30 & 46.9 & .8 & .3 & 30.3 & 21.3 \\
\hline 31 & 46.9 & .6 & .5 & 30.3 & 21.4 \\
\hline 32 & 46.6 & .7 & .3 & 30.3 & 21.5 \\
\hline 33 & 46.5 & .9 & .3 & 30.4 & 21.5 \\
\hline 34 & 46.0 & 1.0 & .4 & 30.2 & 2 t. 5 \\
\hline 35 & 46.0 & 1.6 & .5 & 29.8 & 21.3 \\
\hline
\end{tabular}

'T'Aвı: 2.-Chemical analyses (in percent) of dolomite samples 36-43 [Analyst, Esther Claffy]

\begin{tabular}{|c|c|c|c|c|}
\hline No. & $\mathrm{SiO}_{2}$ & $\mathrm{R}_{2} \mathrm{O}_{3}$ & $\mathrm{CaCO}_{3}$ & $\mathrm{MgCO}_{3}$ \\
\cline { 1 - 2 } 36 & 1.59 & 0.36 & 53.60 & 44.36 \\
37 & 1.35 & .38 & 53.60 & 44.67 \\
38 & 1.70 & .41 & 53.19 & 44.70 \\
39 & 9.93 & 1.08 & 49.19 & 39.80 \\
40 & 7.33 & .43 & 50.41 & 41.83 \\
41 & .84 & .31 & 53.99 & 44.86 \\
42 & 1.56 & .40 & 53.58 & 44.46 \\
43 & 1.58 & .26 & 53.60 & 44.56 \\
& & & & \\
\hline
\end{tabular}


1 to 35. The section was measured from the top of the cliffs (about 120 feet above the flat on the north side of the hill), southward over the middle peak and across the southwest part of the quarry, down to the cliffs south of the quarry floor. Although the section is not continuous, it indicates the chemical composition and the lithologic characteristics of the dolomite along one traverse line across the widest part of the hill. The stratigraphic breaks caused by each fault are noted in the section.

Section of the Middle Cambrian(?) dolomite deposit in Stevens County, Wash.

Northport limestone of Weaver (1920):

14. Dolomite, light- and dark-gray. Contains black irregular masses strongly mottled with light-gray irregular dots and streaks. Forms lowest cliff ledge at southwest end of quarry face. Sample 35 of light-gray dolomite from near top of unit. Sample 34 of black mottled dolomite from $13 \mathrm{ft}$ above base of unit.

13. Dolomite, light-gray. Contains irregular black-gray masses. Veins and thin stringer's of quartz constitute 1 to 5 percent of rock (estimate). Samples 32 and 33 from middle of unit

12. Dolomite, as in unit 11, but slightly darker gray in upper part of the unit. Contains veins and irregular lenses of quartz. Sample 31 from top of unit

Feet

1. Dolomite, faint-blue to dull-light-gray, finely to medium crystalline, slightly vitreous on fresh fracture, unbedded or thick-bedded. Beds much shattered and contain thin quartz veins on joint faces. Sample 30 from $2 \mathrm{ft}$ below top of unit. Sample 29) from $30 \mathrm{ft}$ above base of unit. Sample 28 from $4 \mathrm{ft}$ above base of unit.---

Unit 11 is broken by one of the younger normal faults. The thickness of duplicated beds is unknown.

10. Dolomite, pale- and light-gray, some beds dark gray, no black-gray masses or beds; finely crystalline, dense, hard, slightly vitreous on fresh fracture. Contains some quartz in 1 to $25 \mathrm{~mm}$ veins which follow joints. Quartz more abundant in a 6 -ft wide zone, 4 to $10 \mathrm{ft}$ east of a dike intrusion. Sample 27 from $1 \mathrm{ft}$ below top of unit. Sample 26 from $6 \mathrm{ft}$ above base of unit. Sample 25 from base of unit

The section between units 9 and 10 is intruded by a dike and broken by one of the older normal faults. The throw probably was small, but the thickness of duplicated beds is unknown.

9. Dolomite, light-gray, fine to microcrystalline, thick-bedded, dense. Some irregular masses of black dolomite. Sample 24 from top of unit

8. Dolomite, as in units 5 to 7 , but contains smaller and fewer blackgray masses. Veins and stringers of siliceous dolomite and quartz still present. Sample 23 from $16 \mathrm{ft}$ below top of unit. Sample 22 from $24 \mathrm{ft}$ above base of unit. Sample 21 from $12 \mathrm{ft}$ above base of unit. 
Section of the Middle Cambrian (?) dolomite deposit in Stevens County, Wash.-Continued

Northport limestone of Weaver (1920)-Continued

6. Dolomite, similar to unit 5 . Sample 18 from $6 \mathrm{ft}$ below top of unit. Sample 17 from $48 \mathrm{ft}$ above base of unit. Sample 16 from 24 ft above base of unit.

5. Dolomite, dull-gray, thick-bedded, medium-crystalline to sugary ; alternating bands of black-gray dolomite mottled with small light-gray spots and streaks. Contains a few veins of cherty dolomite and quartz. Sample 15 from $8 \mathrm{ft}$ below top of unit. Sample 14 from $38 \mathrm{ft}$ above base of unit. Sample 13 from 12 $f t$ above base of unit.

4. Dolomite, dull-gray, gray, and blue-gray banded, finely to medium crystalline, thick-bedded or unbedded. Sample 12 from top of unit. Sample 11 from $23 \mathrm{ft}$ below top of unit. Sample 10 from $32 \mathrm{ft}$ above base of unit

3. Dolomite, middle part of unit covered. Dolomite dull gray in lower part, faint blue gray in upper part. Sample 9 from top of unit. Sample 8 from $10 \mathrm{ft}$ below top of unit. Sample 7 from $16 \mathrm{ft}$ above base of "unit

2. Dolomite, pale-gray, white-gray to faint-blue-gray, hard, finely to medium crystalline. Contains a little sericite along joint faces; also irregular veinlets of white quartz. Weathers pale gray. Sample 6 from top of unit. Sample 5 from $21 \mathrm{ft}$ below top of unit. Sample 4 from $23 \mathrm{ft}$ above base of unit

1. Dolomite, thick-bedded, pale-gray, finely to medium crystalline, dense, hard. Some irregular beds of black-gray dolomite mottled light gray in spots or stringers $2 \mathrm{~mm}$ wide and 10 to $25 \mathrm{~mm}$ long. Some beds contain veins $1 / 25$ to $8 \mathrm{in}$. thick of white glassy quart\% along joint faces. Sample 2 from $29 \mathrm{ft}$ below top of unit Sample 1 from base of unit

Total

\section{SILICA AND OTHER IMPURITIES}

Silica as quartz, the principal impurity in the dolomite, is so abundant and irregularly distributed that much of the deposit may not be usable as a magnesium ore. (See pls. 14, 15.) Quartz occurs as (1) veinlets 0.5 to $5 \mathrm{~mm}$ thick (fig. 32), (2) irregularly walled and some smooth-walled veins as much as 15 inches thick (fig. 36), (3) sharp, angular ioslated fragments or nodules (fig. 35), (4) solid or: vuggy cement around dolomite breccia fragments (fig. 37), and (5) vuggy masses (fig. 33). In addition, silica doubtless is present as microscopic quartz grains and in chemical combination as silicate minerals. Neither chert nor chalcedony was identified in the dolomite.

Silica is most conspicuous in white glassy quartz veins, most of which (see figs. 32, 34, 36) were deposited along joints. Much of the quartz in the breccias is stained tan buff and is slightly granular. The silica in the vuggy masses is dull gray and porous and superficially resembles siliceous sinter. The white quartz veins were deposited along intersecting sets of joints (fig. 32), and the quartz in the breccia 


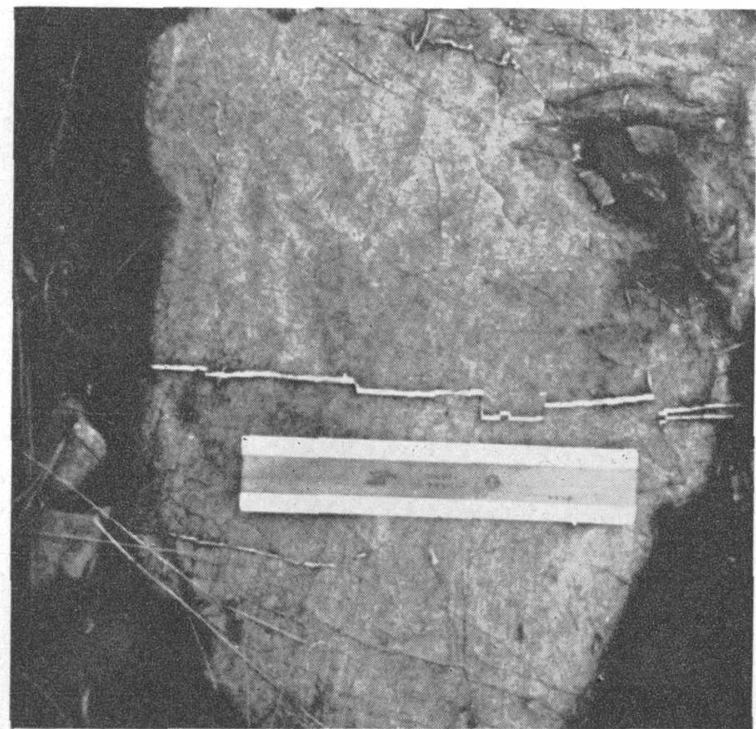

Figure 32.-Continuous white quartz vein on intersecting joints.

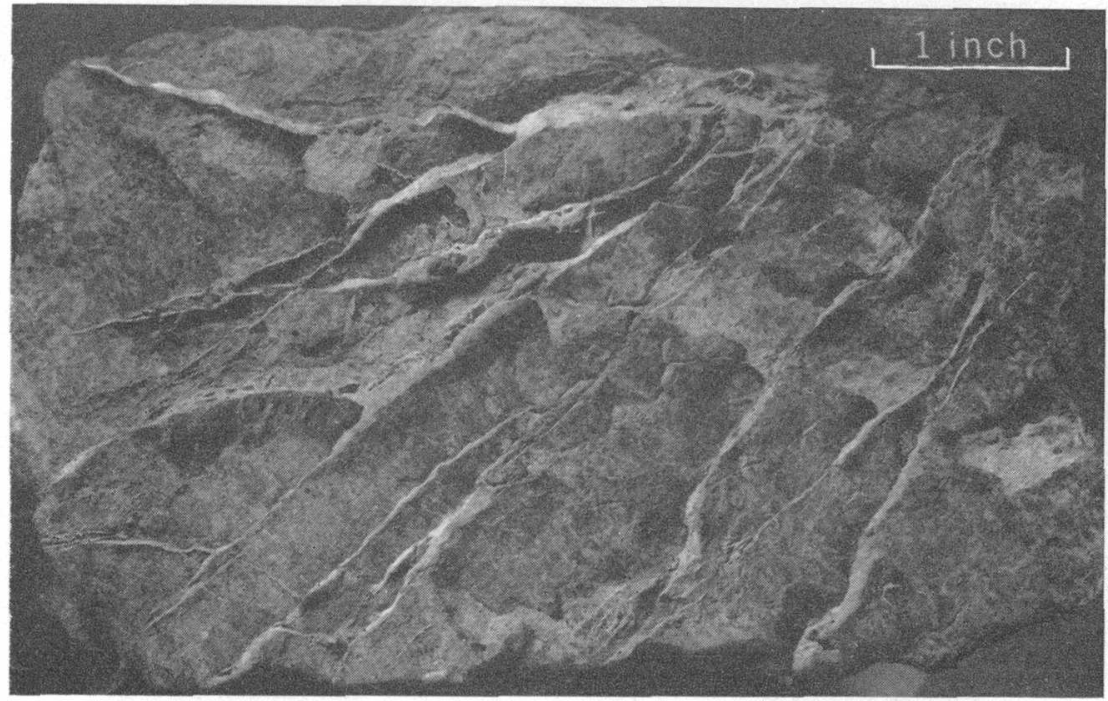

Figure 33.--Irregularly intersecting vuggy quartz veins in dark-gray dolomite.

zones is unbroken around the dolomite fragments, thus indicating that the silica was deposited after jointing and faulting. Quartz veins are common in the metamorphosed pre-Cambrian and Paleozoic rocks of northeastern Washington and probably are related in origin to the granites that intruded these rocks in Tertiary time.

The samples of crushed dolomite from the quarry have averaged more than 3 percent silica, which is probably representative of the 


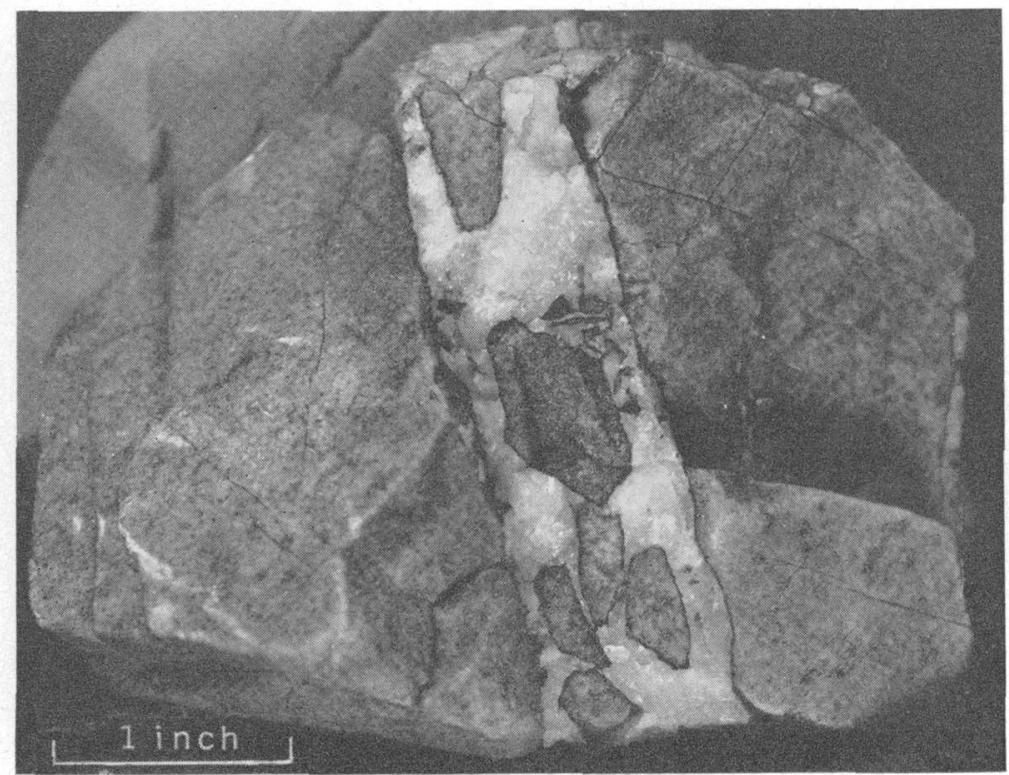

Figure 34.- White quartz vein enclosing angular fragments of dolomite.

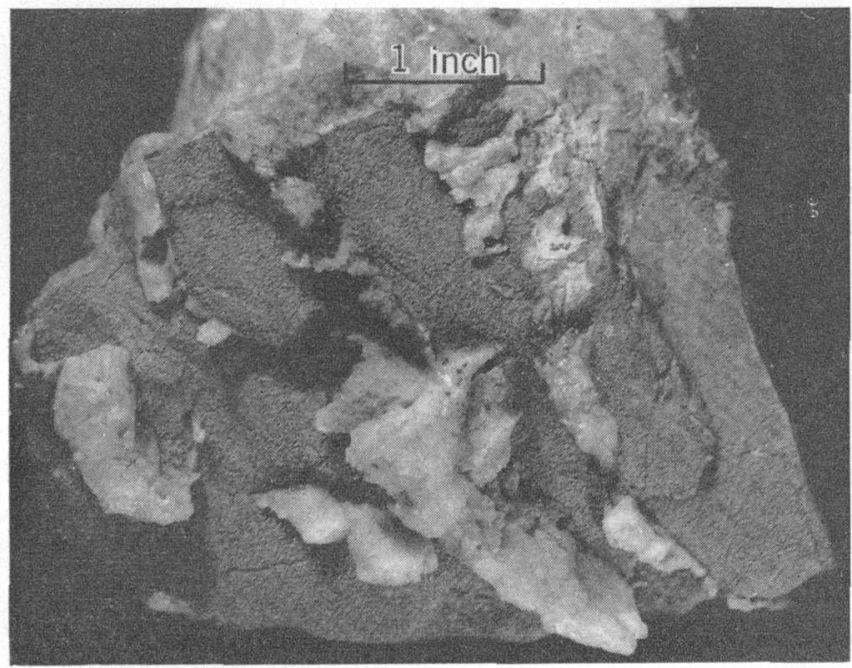

Figure 35.-Angular nodules of white quartz in dull-gray dolomite.

entire deposit. However, the siliceous zones shown on the map may contain as much as 10 or 15 percent of $\mathrm{SiO}_{2}$.

The other principal impurities in the dolomite are oxides of aluminum and iron. The relative amount of each is unknown as they are represented in the analyses as $\mathrm{R}_{2} \mathrm{O}_{3}$. In many of the samples, however, the $\mathrm{R}_{2} \mathrm{O}_{3}$ is less than 0.8 percent, an amount that is not excessively objectionable in reducing dolomite with ferrosilicon. The aluminum 


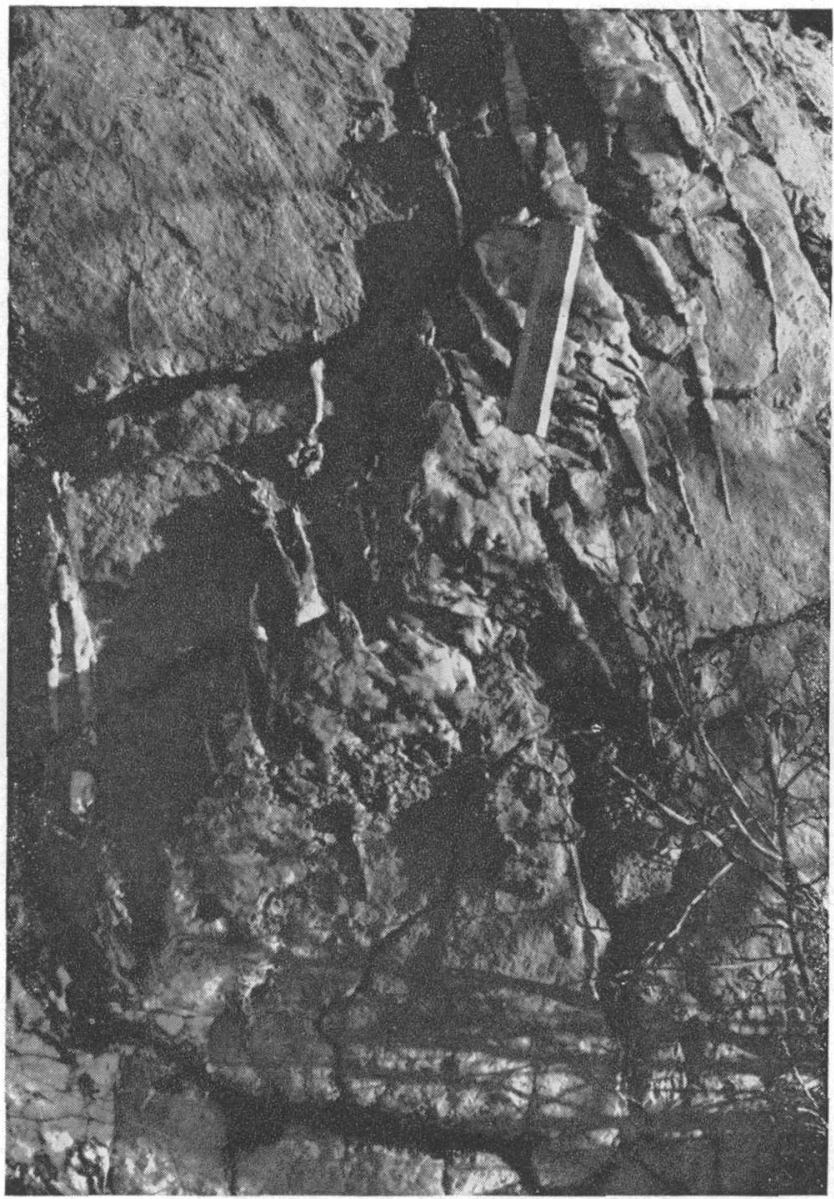

Figure 36.-Large vein of white quartz.

oxide probably represents original argillaceous material in the dolomite, but much of the iron oxide may have been introduced later.

\section{ORIGIN OF THE DOLOMITE}

Dolomite may be formed either during or closely following deposition of the original sediment in the sea, or later by alteration of original limestone by magmatic magnesium-bearing solutions.

Replacement dolomite characteristically contains unreplaced blocks and fragments of limestone, many open cavities, and irregular contacts. It is commonly coarse grained and exhibits considerable variation in grain size. These features have been described by Hewett (1931, p. 57-61; 1928, p. 821-863) and have been further treated by the writer in his report on the dolomite deposit at Sloan, Nev. (Deiss, 1952 , p. 132-134). The dolomite at Marble is a bedded deposit and 


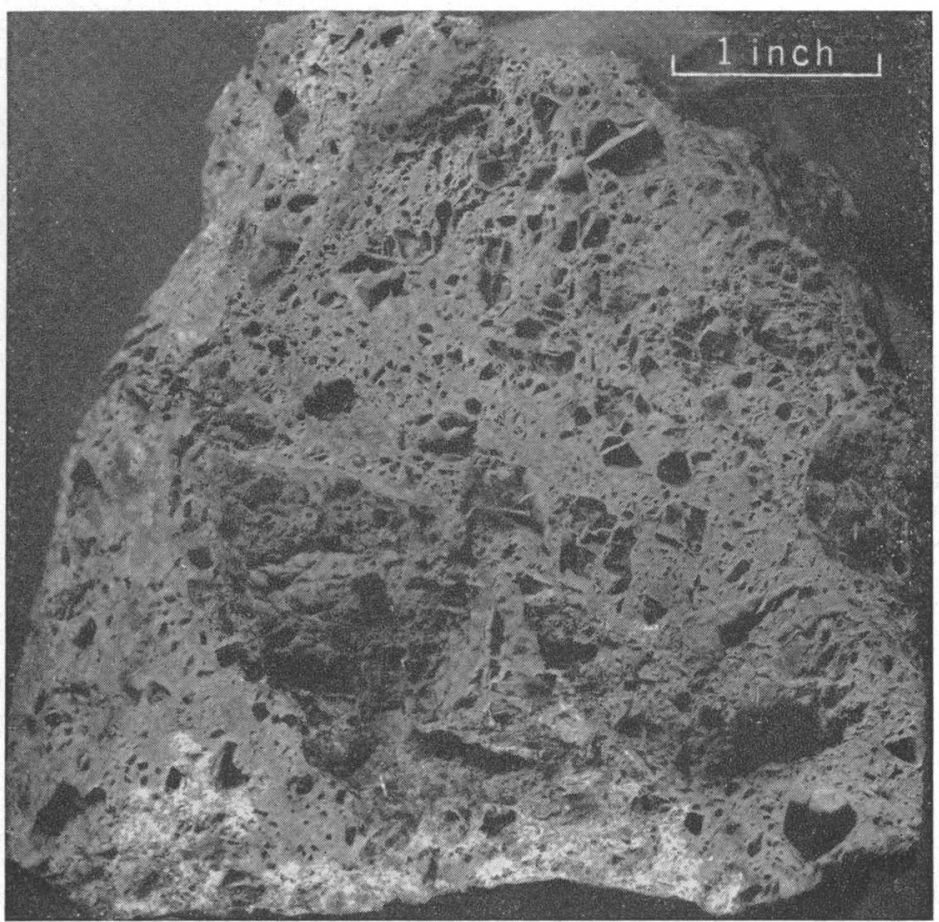

Figure 37,-Buff-colored quartz surrounding leached fragments of dolomite breccia.

contains none of the characteristics indicative of replacement origin. Therefore, it is thought that dolomitization occurred at or shortly following the time of deposition of the original sediment. It should be pointed out that much of the Northport limestone, of which the dolomite near Marble is a part, is limestone. However, the relations of the two rocks were not exposed for observation in the field. Park and Cannon (1943, p. 45 ) observed that the location of bedded dolomite in the Metaline district nearby bears no direct relation to deformation structures, and they concluded that "regional dolomitization was probably accomplished before the introduction of the ore-bearing solutions, and it may have taken place early in the structural history." The same conclusion applies to the dolomite at Marble.

\section{MINING CONDITIONS AND METHODS}

The steep-sided dolomite hill and the surrounding nearly level flat (fig. 29) provide ideal conditions for economical mining and for operation of the crushing and screening plant and the railroad spur. The climate in the valley of the Columbia River is not so severe as might be expected near the 49th parallel at an altitude of 1,900 feet. Snow retards quarry operations during some winters but rarely causes a 
complete stoppage of work. F. W. Sandoz (personal communication, November 19,1943) says: "Snow reduces production 10 percent in open winters and as much as 20 percent during severe winters."

\section{QUARRY OPERATIONS}

The dolomite is mined by benching the main quarry face. The lower face is shot at the same rate as the benches in order that rock blasted on the benches will fall directly to the quarry floor. Boulders larger than 30 inches in diameter are broken by plug shots, and the rock is loaded into buggies by either a $31 / 2^{-}$or a $33 / 4$-yard power shovel. One shovel at a time handles enough rock to supply the crushing plant, which has a rated capacity of 2,500 tons for 8 hours' operation. Except for the small amount shoved off the benches with bulldozers, all rock is moved on the quarry floor. The buggies dump the dolomite into a hopper, from which the dolomite moves on a steel conveyor to a "grizzly" and then to the primary crusher.

\section{CRUSHING AND SCREENING}

The dolomite is crushed in three gyratory crushers and screened to four sizes, referred to as grades $1,2,3$, and fines. The sizes in grade 1 are minus $1 \frac{1}{2}$, plus 1 inch; in grade 2 are minus 1 , plus $1 / 2$ inch; in grade 3 are minus $1 / 2$, plus $1 / 4$ inch; and fines are minus $1 / 4$ inch. The crushed rock is loaded by gravity from storage bins into open railroad cars on both sides of the storage building. The fines are loaded similarly into cars, buggies, and trucks from bins in the fines building. About 20 percent of the rock that enters the plant results in fines not used for ore.

\section{PRODUCTION}

The quarry and mill were put in operation April 16, 1943. Until mid-November 1943 , about 23,400 tons of dolomite a month was quarried and milled and 19,500 tons was shipped. The largest tonnage quarried in 8 hours "probably was 800" (F. W. Sandoz, personal communication, November 19, 1943). Failure to attain greater production was attributed to a shortage of railroad cars. The manpower shortage at the Spokane Works of the Electro Metallurgical Co. has held production to approximately 40 percent of the plant's rated capacity, which in turn necessitated reduced operations at the quarry. In mid-November 1943, production at the quarry was reduced to 8 cars per day, or a monthly average of 11,000 tons of ore plus 2,200 tons of fines, a total of 13,200 tons. The plant was closed on January 1, 1945. In 1952 operations were resumed at the quarry and the Spokane magnesium plant, but no details concerning these recent operations are available. 


\section{SEI_ECTED BIBLIOGRAPHY}

Daly, R. A., 1912, Geology of the North American Cordillera at the forty-ninth parallel : Canada Geol. Survey Mem. 38, pt. 1, 573 p.

Deiss, C. F., 1952, Dolomite deposit near Sloan, Nev.: U. S. Geol. Survey Bull. 973-C, p. 107-141.

Flint, R. F., 1936, Stratified drift and deglaciation of eastern Washington: Geol. Soc. America Bull., v. 47, p. 1849-1884.

Hewett, D. F., 1928, Dolomitization and ore deposition : Econ. Geology, v. 23, p. 821-863.

1931, Geology and ore deposits of the Goodsprings quadrangle, Nevada: U. S. Geol. Survey Prof. Paper 162, p. 57-61.

Landes, Henry, 1934, The mineral resources of the Columbia River basin in eastern Washington and parts of northern Idaho: U. S. 73d Cong., 1st sess., H. Doc 103, v. 2, p. 1068-1107.

Pardee, J. T., 1918, Geology and mineral deposits of the Colville Indian Reservation, Wash.: U. S. Geol. Survey Bull. 677, $186 \mathrm{p}$.

Park, C. F., Jr., 1938, Dolomite and jasperoid in the Metaline district, northeastern Washington : Econ. Geology, v. 33, p. 709-729.

Park, C. F., Jr., and Cannon, R. S., Jr., 1943, Geology and ore deposits of the Metaline quadrangle, Washington: U. S. Geol. Survey Prof. Paper 202, $81 \mathrm{p}$.

Weaver, C. E., 1920, The mineral resources of Stevens County: Wash. [State] Geol. Survey Bull. 20, $350 \mathrm{p}$. 